\title{
EFFECT OF GRINDING FINENESS OF FLY ASH ON THE PROPERTIES OF GEOPOLYMER FOAM
}

Present paper deals with the development of geopolymer foam prepared from ground F class power station fly ash. The effect of the fly ash fineness on the rheology of the geopolymer paste and the foam properties have been investigated. The raw fly ash was ground in a ball mill for various duration, 5, 10, 20, 30, 60 and $120 \mathrm{~min}$. Geopolymer paste was prepared from the raw and ground fly ash with $\mathrm{NaOH}$ - sodium silicate mixture as alkaline activator. Geopolymer foam production was made using $\mathrm{H}_{2} \mathrm{O}_{2}$ as foaming agent. Additionally, the geopolymer material structure was investigated by Fourier transform infrared spectrometer, the foam cell structure was monitored using optical microscopy. The rheological behaviour of the geopolymer paste changed due to the grinding of fly ash (from Bingham plastic to Newtonian liquid). Grinding of fly ash has a significant effect on the physical properties as well as on the cell structure of the geopolymer foam.

Keywords: fly ash, grinding, rheology, geopolymer foam, cell structure

\section{Introduction}

Geopolymers are amorphous alumino-silicate materials formed due to reaction between alumino-silicates and oxides with alkaline media ( $\mathrm{NaOH}, \mathrm{KOH}$ solution). Geopolymers can be synthesized at ambient or elevated temperature by alkaline activation of alumino-silicates obtained from mineral materials (perlite), industrial waste (fly ash, slag or red mud) and calcined clay (metakaolin) [1-5].

Alkali activation of these materials together with chemical foaming led to the synthesis of inorganic foam. As foaming agent hydrogen-peroxide [1,6,10] aluminum powder [7-10] or sodiumperborate [6] can be used. The cellular structure of geopolymers can be produced by introducing a large volume fraction of air bubbles into the paste. In this case for the stabilization of the wet foam organic monomers can be used such as detergents, resin soap, glue resins, saponin, and hydrolyzed proteins $[10,11]$.

Geopolymer foam (GPF) possess good physico-chemical and mechanical properties like low density, relative high strength, fire and chemical resistance, thermal stability, good thermal insulation properties [6-9].

The hydrogen-peroxide is thermodynamically unstable and therefore can be easily decomposed to water and oxygen gas with the latter playing the role of the geopolymer paste foaming agent $[1,10]$.

Based on literature [7,9] the geopolymer foam stability of the pore structure at the fresh state strongly depends on the viscosity of the initial mix. The viscosity can be easily changed by the amount of added liquid activator, i.e. by the liquid/solid ratio. However, rheology of suspensions can be controlled by the size reduction of the solid component, by grinding.

The main aim of the research is to optimize the grinding fineness in order to produce a homogeneous cell structure with appropriate mechanical properties i.e. to investigate the effect of the fly ash fineness on the rheology of the geopolymer paste and the foam properties (pore size distribution, porosity, strength, material structure, cell structure of the geopolymer foam).

\section{Materials and methods}

Landfilled brown coal fly ash collected from Tiszaújváros (Hungary) was used as main component for geopolymer foam production. Moisture content was $21.49 \%$. Characteristic particle size values of raw fly ash were $\mathrm{x}_{50}=78.04 \mu \mathrm{m} ; \mathrm{x}_{80}=145.65 \mu \mathrm{m}$. The specific surface area (SSA) of raw fly ash was found to be $703.8 \mathrm{~cm}^{2} / \mathrm{g}$. The main oxidic components of raw fly ash were following: $\mathrm{SiO}_{2}(60.9 \%), \mathrm{Al}_{2} \mathrm{O}_{3}(27.1 \%), \mathrm{Fe}_{2} \mathrm{O}_{3}(4.98 \%), \mathrm{CaO}$ (1.55\%), $\mathrm{MgO}(0.94 \%)$ and $\mathrm{SO}_{3}(0.068 \%)$.

The raw fly ash was mechanically activated for various duration $(5,10,20,30,60$ and $120 \mathrm{~min})$ in a tumbling laboratory ball mill with the size of $\varnothing 305 \times 305 \mathrm{~mm}$. During the grinding the specific grinding energy was measured. The particle size distribution of the raw and ground fly ashes had been investigated by Horiba LA950 V2 type laser particle size analyzer, "outer"

\footnotetext{
* INSTITUTE OF RAW MATERIAL PREPARATION AND ENVIRONMENTAL PROCESSING, UNIVERSITY OF MISKOLC, 3515 MISKOLC, HUNGARY

** MTA-ME MATERIALS SCIENCE RESEARCH GROUP, UNIVERSITY OF MISKOLC, 3515 MISKOLC, HUNGARY INSTEAD OF INSTITUTE OF PHYSICAL METALLURGY, METALFORMING AND NANOTECHNOLOGY, UNIVERSITY OF MISKOLC, 3515 MISKOLC, HUNGARY 
specific surface area was calculated from distribution data by software using shape factor 1 .

The geopolymer foam production shows Fig. 1. Waterglass and $12 \mathrm{M} \mathrm{NaOH}$ solution were used as alkaline activator. The liquid/solid ratio (L/S) of geopolymer paste was 0.67 . Hydrogen peroxide (30 mass \% solution) was used as chemical foaming agent. Amount of $\mathrm{H}_{2} \mathrm{O}_{2}$ solution was $3 \mathrm{w} / \mathrm{w} \%$ in fly ash mass. The heat curing was carried out at $50^{\circ} \mathrm{C}$ for 10 hours. Three specimens of geopolymer foam were made in all cases for the strength investigation. The uniaxial compressive strength was measured at the age of 7 days. In addition specimen density, cell structure and pore size of geopolymer foam and viscosity of the geopolymer paste were examined.

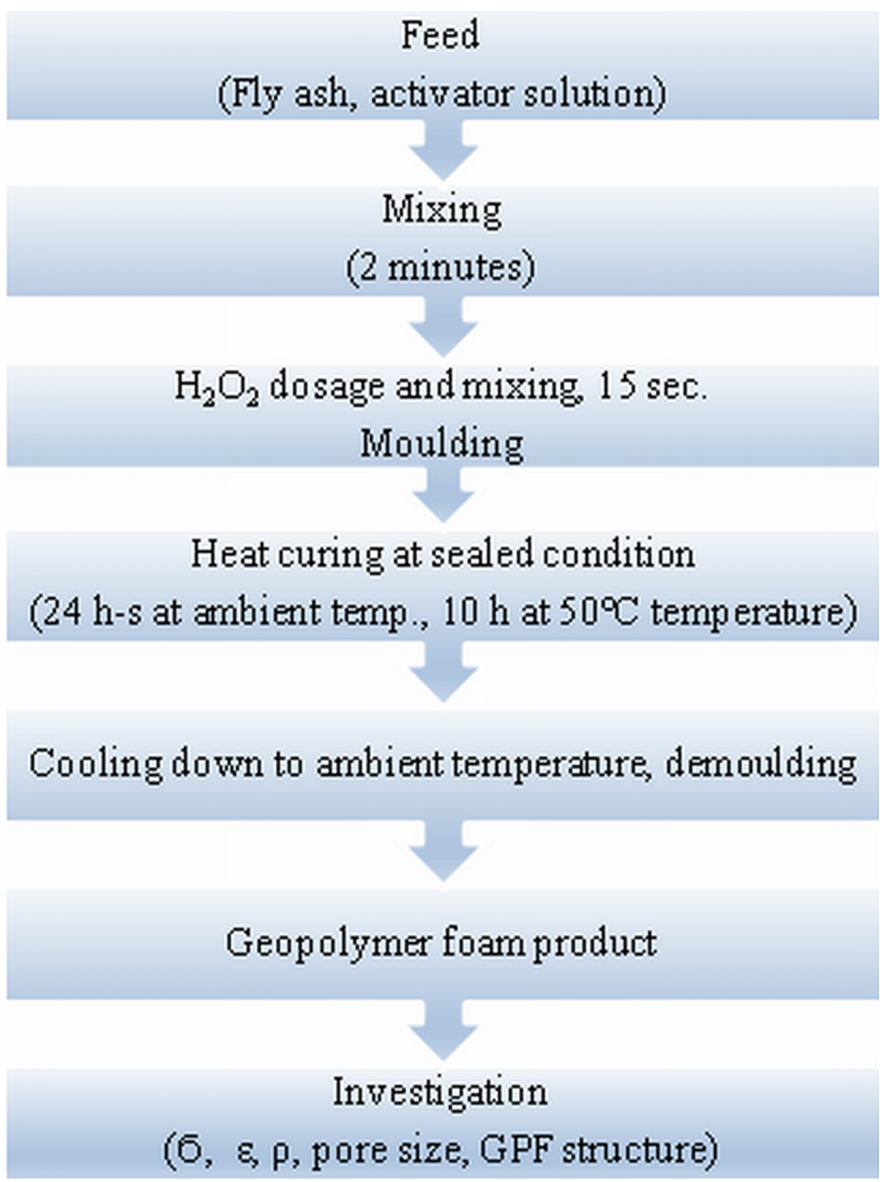

Fig. 1. Geopolymer foam production

In order to measure the rheological properties of the geopolymer paste, it had to be diluted to $\mathrm{L} / \mathrm{S}$ ratio of 0.82 . Denser paste could not be measured due to the high viscosity of the paste. The measurements were carried out with cylindrical geometry and flat geometry measuring head where cylinders were not able to use.

The cell size and shape in geopolymer foam was monitored using C. Zeiss Discovery V.12 optical microscope. The material structure of the geopolymer foam products was investigated by JASCO FT-IR 4200 type Fourier Transformed Infrared Spectrometer in reflection mode, using a diamond ATR.

\section{Results and discussion}

\section{Effect of grinding on the fly ash fineness}

Fig. 2 shows the produced specific surface area and median particle size $\left(\mathrm{x}_{50}\right)$ as function of specific grinding energy. Based on this figure it can be stated, that SSA increasing almost linearly as function of specific grinding energy. After 120 minutes grinding in a ball mill $10.79 \mu \mathrm{m}$ median particle size was achieved from the initial value of $78.04 \mu \mathrm{m}$. In addition the "outer" specific surface area increase was significant; from $703.8 \mathrm{~cm}^{2} / \mathrm{g}$ to $5876.8 \mathrm{~cm}^{2} / \mathrm{g}$ using $368 \mathrm{~kJ} / \mathrm{kg}$ specific energy input.

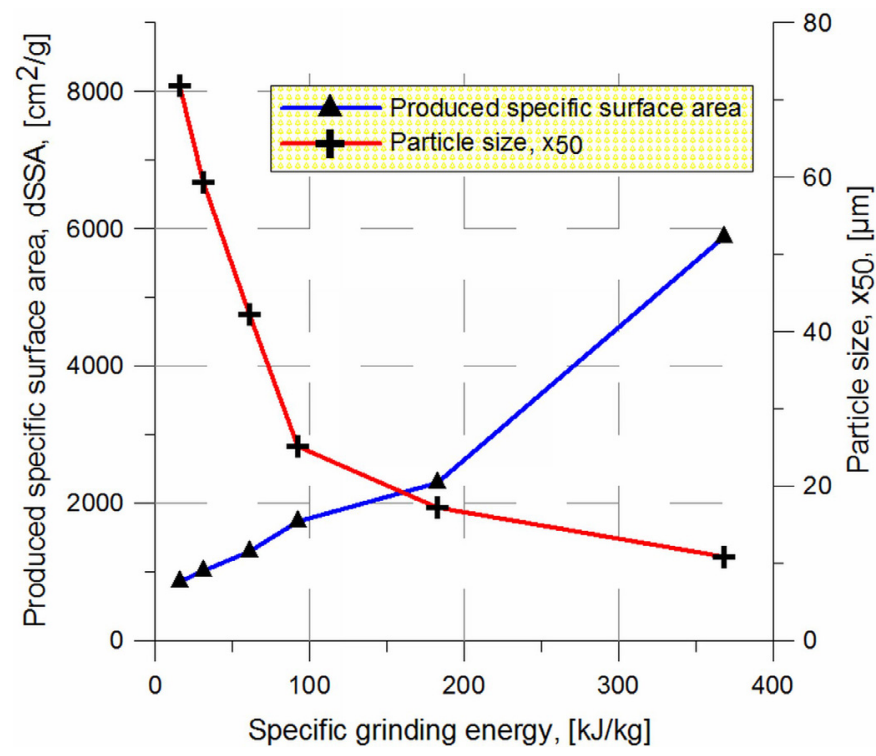

Fig. 2. Grinding kinetics of fly ash

\section{Effect of fly ash fineness on the geopolymer paste viscosity}

The examined sample of fly ash and activator mixture showed changing rheological behaviour according to the fineness of the fly ash powder (Fig. 3). The rheology of the mixture of the activator and the raw fly ash and those were taken after 5 minutes grinding time were not possible to measure in the actual device has been being used due to particles were too coarse to fit into the gap of the plate geometry of the viscometer. According to the measurement, mixtures with above $25 \mu \mathrm{m} \mathrm{x}_{50}$ has shown Bingham-plastic behaviour with yield stress of $15 \mathrm{~Pa}$, however, grinding has decreased the coefficient of rigidity $[\eta, \mathrm{mPas}]$. If the fineness is higher the rheology changed and the mixture became Newtonian liquid. When the specific surface area of fly ash was $5876.8 \mathrm{~cm}^{2} / \mathrm{g}$ the viscosity has reached $60 \mathrm{mPas}$. Based on Fig. 3 it can be observed that the increase of specific surface area of fly ash decreased the viscosity of geopolymer paste.

\section{Geopolymer foam strength and specimen density}

In Fig. 4 the compressive strength and specimen density values of geopolymer foam can be seen as function of grinding fineness of fly ash. Based on this figure it can be stated that the low specimen density resulted in low compressive strength. 


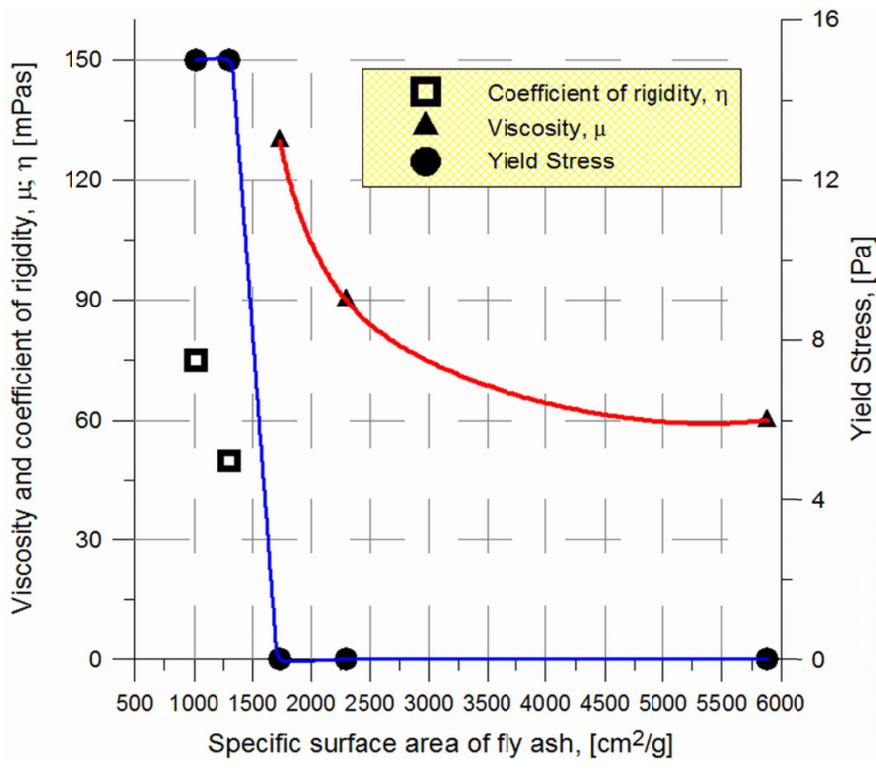

Fig. 3. Effect of grinding fineness on rheology of geopolymer pastes

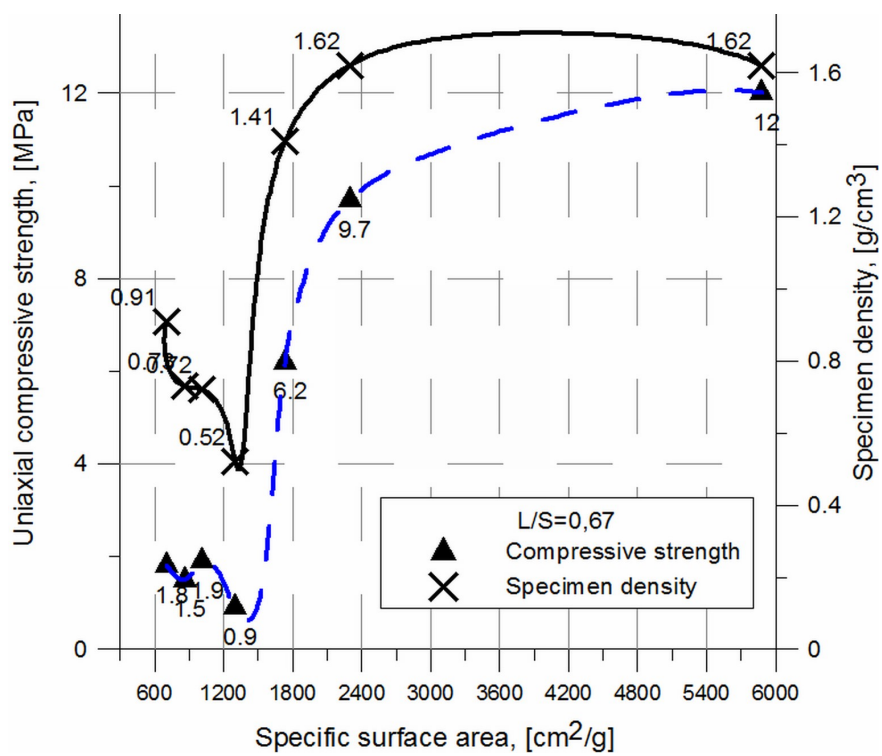

Fig. 4. Effect of grinding fineness of fly ash on geopolymer foam strength and density

When the specific surface area of fly ash was in the range of $700-1300 \mathrm{~cm}^{2} / \mathrm{g}$ the compressive strength value of geopolymer foam was relatively low (between 0.9 and $1.9 \mathrm{MPa}$ ). The lowest compressive strength was $0.9 \mathrm{MPa}$ which belonged to $1300 \mathrm{~cm}^{2} / \mathrm{g}$ SSA of fly ash. In this case the specimen density of geopolymer foam was the lowest, with $0.52 \mathrm{~g} / \mathrm{cm}^{3}$. Above $~ 1700 \mathrm{~cm}^{2} / \mathrm{g} \mathrm{SSA}$ of fly ash the compressive strength and specimen density of geopolymer foam increased. The highest compressive strength (12 MPa) and specimen density $\left(1.62 \mathrm{~g} / \mathrm{cm}^{3}\right)$ can be achieved at $5876.8 \mathrm{~cm}^{2} / \mathrm{g} \mathrm{SSA}$ of fly ash $\left(\mathrm{x}_{50}=10.79 \mu \mathrm{m}\right.$ instead $\mathrm{x}_{50}=$ $\left.10.79 \mathrm{~cm}^{2} / \mathrm{g}\right)$.

\section{Cell structure of geopolymer foam}

The mean pore size of geopolymer foam can be seen in Fig. 5. The geopolymer foam had the highest mean pore size when the specific surface area of fly ash was reached $1300 \mathrm{~cm}^{2} / \mathrm{g}$ $\left(\mathrm{x}_{50}=42.23 \mu \mathrm{m}\right.$ instead $\left.\mathrm{x}_{50}=42.23 \mathrm{~cm}^{2} / \mathrm{g}\right)$. In this case the mean pore size was $2.6 \mathrm{~mm}$. When the specific surface area of fly ash was below $857 \mathrm{~cm}^{2} / \mathrm{g}$ or above $5800 \mathrm{~cm}^{2} / \mathrm{g}$ the mean pore size of geopolymer foam was below $0.7 \mathrm{~mm}$.

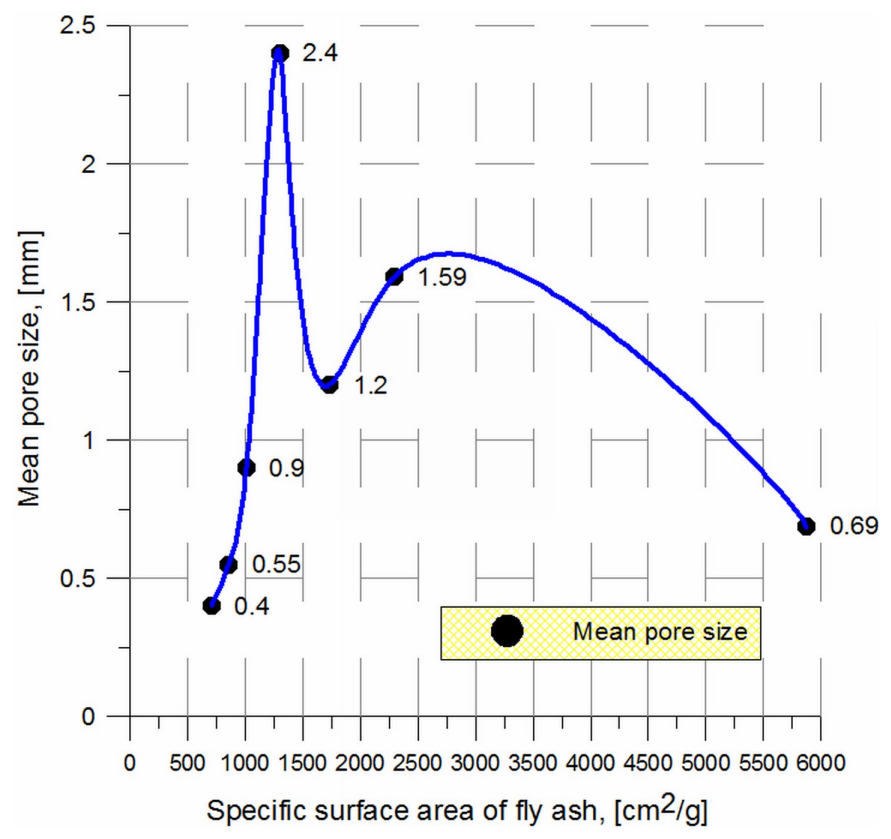

Fig. 5. Mean pore size of geopolymer foam

Based on these results it can be stated that the formed cell structure depends on the rheology of geopolymer paste. Due to the high viscosity of geopolymer paste the formation of pore was inhibited, the pore size of geopolymer foam were too small (few macropores are detected (Fig. 6A)). Due to too low viscosity the oxygen gas has gone easily from the geopolymer paste. As

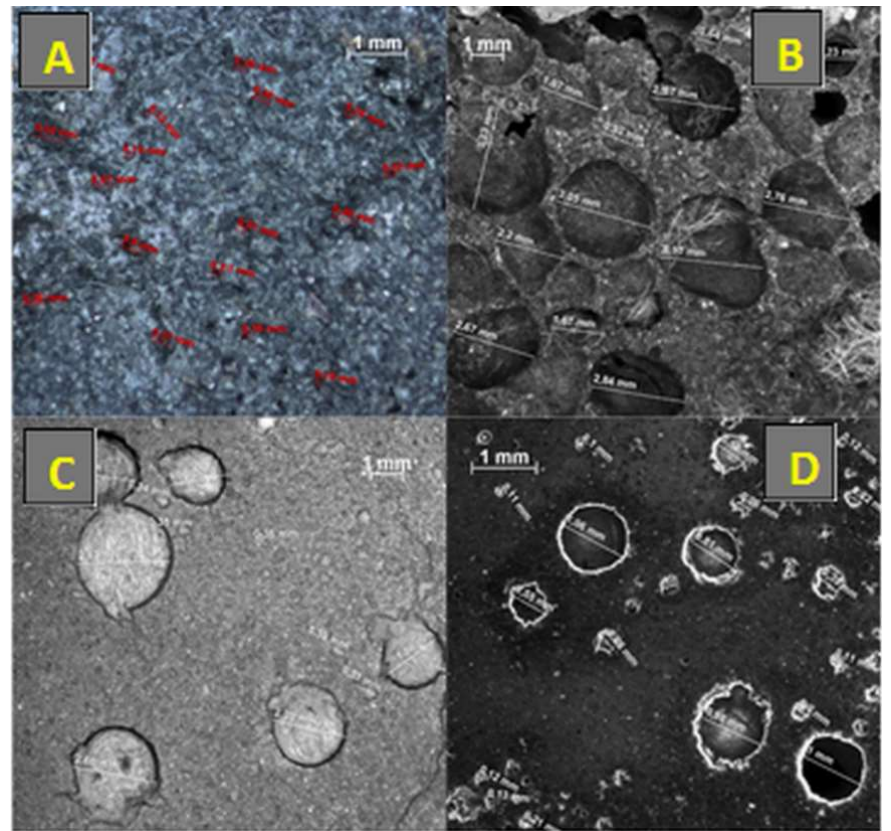

Fig. 6. Optical microscopy images of GPF (A. 0 min, B. 20 min, C. $60 \mathrm{~min}, \mathrm{D} .120 \mathrm{~min}$ grinding time of fly ash) 
a result of this the geopolymer foam had compact structure with few bigger pores (macropores are below $2 \mathrm{~mm}$ (Fig. 6C and D)). The density increased up to $1.62 \mathrm{~g} / \mathrm{cm}^{3}$.

\section{Material structure}

Based on the FTIR spectra of raw and mechanically activated fly ash (Fig. 7), significant absorbance can be observed at $1054 \mathrm{~cm}^{-1}$, which is usually attributed to $\mathrm{T}-\mathrm{O}-\mathrm{Si}(\mathrm{T}=\mathrm{Si}$ or $\mathrm{Al})$ bonds asymmetric stretching vibration, while at $546 \mathrm{~cm}^{-1}$ can be assigned to $\mathrm{Si}-\mathrm{O}-\mathrm{Si}$ and $\mathrm{Al}-\mathrm{O}-\mathrm{Si}$ bonds symmetric stretching vibration.

Peak corresponding to $796 \mathrm{~cm}^{-1}$ related to $\mathrm{Si}-\mathrm{O}-\mathrm{Si}$ bonds symmetric stretching vibration $[12,13]$. It can be stated, that the increasing grinding time resulted in slightly higher peak intensities, which can be associated to higher infra absorbance due to higher specific surface area of fine particles.
However, based on the FTIR spectra of geopolymer foams (Fig. 8) it can be observed that the grinding of fly ash caused changing of geopolymer foam material structure. Based on $\mathrm{Pa}-$ nias et al [12] peak at $3318 \mathrm{~cm}^{-1}$ corresponding to $-\mathrm{OH}, \mathrm{HOH}$ bonds stretching vibration while the peak at $1641 \mathrm{~cm}^{-1}$ sign the $\mathrm{HOH}$ bonds bending vibration. Peak at $1404 \mathrm{~cm}^{-1}$ related to $\mathrm{O}-\mathrm{C}-\mathrm{O}$ stretching vibration. Peak observed at $1054 \mathrm{~cm}^{-1}$ in the case of fly ash shifted lower wavenumber $\left(992 \mathrm{~cm}^{-1}\right)$ after geopolymerization, which indicates structural reorganization.

It is associated with dissolution of amorphous phase of fly ash in strong alkali media according to Panias et al [12]. The peak intensities of gopolymer foam increased as function of increasing grinding time. It indicates higher rate of geopolymerisation according to Kumar et al [14].

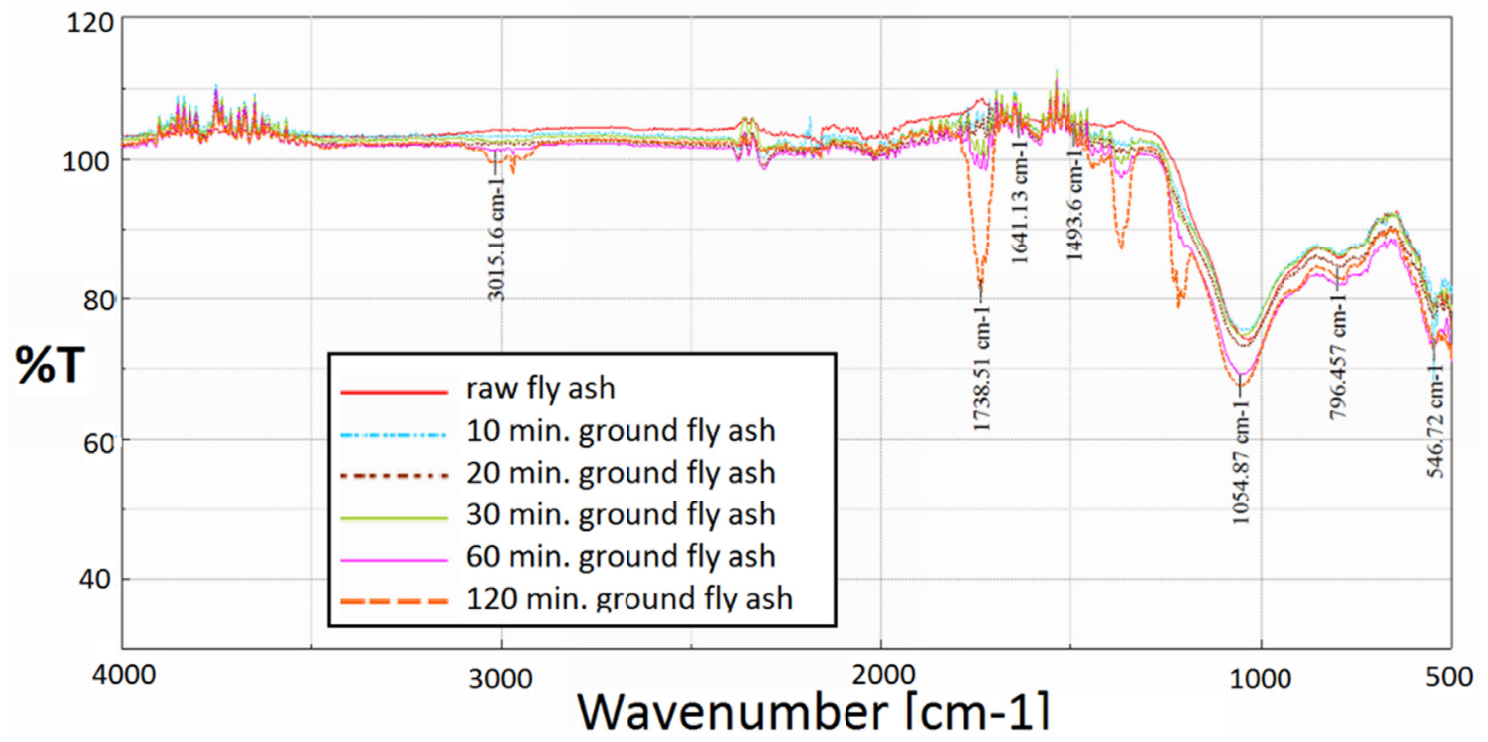

Fig. 7. FTIR spectra of mechanically activated fly ash

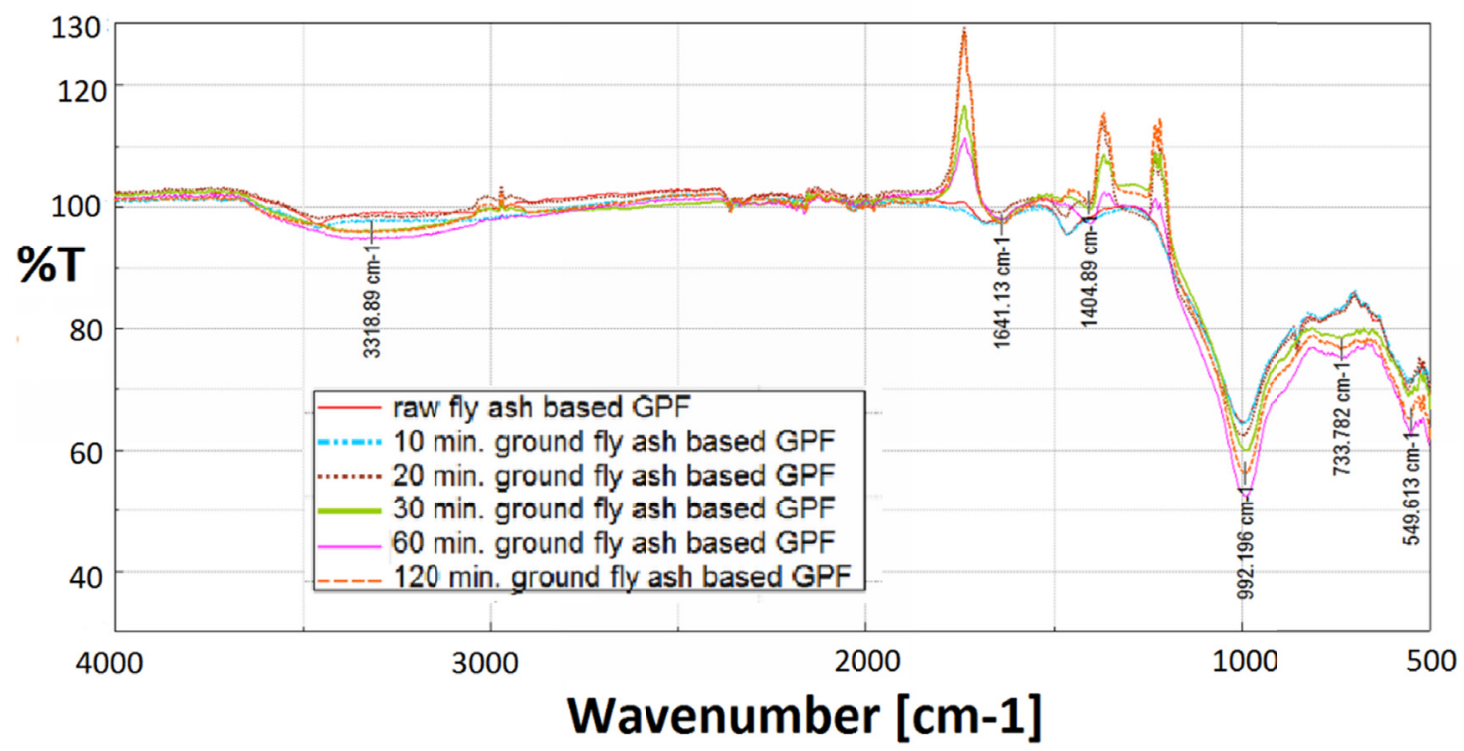

Fig. 8. FTIR spectra of geopolymer foam from mechanically activated fly ash 


\section{Conclusions}

Based on the experimental results presented above the following conclusions can be drawn:

- The rheology of geopolymer paste can be changed by decrease of particle size (increase of specific surface area) of fly ash by keeping constant liquid/powder ratio (L/S).

- Beside constant liquid/powder ratio $(\mathrm{L} / \mathrm{S}=0.82)$ if the specific surface area of fly ash was below $1300 \mathrm{~cm}^{2} / \mathrm{g}$ $\left(<\mathrm{x}_{50}=25 \mu \mathrm{m}\right)$, the geopolymer paste has shown NonNewtonian (Bingham plastic) behaviour with yield stress of $15 \mathrm{~Pa}$. The grinding has decreased the coefficient of rigidity $[\eta, \mathrm{mPas}]$. If the fineness is higher the rheology changes and the mixture become Newtonian liquid.

- The formation of porous structure strongly influences on the rheology of geopolymer paste. If the viscosity of geopolymer paste was low, the geopolymer foam shown quite compact structure with few higher $\left(<x_{\text {mean }}=2 \mathrm{~mm}\right)$ pores (Fig. 6C and D). In this case the generated oxygen gas had gone easily from geopolymer paste. The high viscosity resulted in foam structure with small pores $\left(\mathrm{x}_{\text {mean }}=0.4 \mathrm{~mm}\right)$ (Fig. 6A).

- The compressive strength of geopolymer foam depends on the pore structure. Based on the measurements, the highest porosity $(0.75)$ resulted the lowest compressive strength (0.9 MPa).

- Optimal fly ash fineness $\left(\mathrm{SSA}=1300 \mathrm{~cm}^{2} / \mathrm{g}, \mathrm{x}_{50}=42 \mu \mathrm{m}\right)$ resulted in $0.9 \mathrm{MPa}$ compressive strength and $0.52 \mathrm{~g} / \mathrm{cm}^{3}$ density of geopolymer foam.

\section{Acknowledgement}

The described work was carried in the frame of Center of Excellence of Sustainable Natural Resource Management at the University of Miskolc.
Authors appreciate the help of Akos Debreczeni for strength tests. Furthermore, this work was partially supported by the János Bolyai Research Scholarship of the Hungarian Academy of Sciences.

\section{REFERENCES}

[1] V. Vaou, D. Panias, Miner. Eng. 23 (14), 1146-1151 (2010).

[2] J. Davidovits, Geopolymer chemistry and application, Saint-Quentin France, 2011

[3] J. Davidovits, J. Materials Education 16, 91-138 (1994).

[4] G. Mucsi, J. Lakatos, Z. Molnár, R. Szabó, in D. Cygas, T. Tollazzi (Ed.), Paper 39, Vilnius Gediminas Technical University Press, Vilnius (2014).

[5] K. Komintsas, D. Zaharaki, Mineral Engineering 20, 1261-1277 (2007).

[6] Z. Abdollahnejad, F. Pacheco-Torgal, T. Félix, W. Tahri, J. Barroso Aguiar, Construction and Building Materials 80, 18-30 (2015).

[7] P. Hlaváček, V. Šmilauer, F. Škvára, L. Kopecký, R. Šulc, Journal of the European Ceramic Society 35(2), 703-709 (2015).

[8] W.D.A. Rickard, A. van Riessen, Cement and Concrete Composites 48, 75-82 (2014).

[9] J.G. Sanjayan, A. Nazari, L. Chen, G.H. Nguyen, Construction and Building Materials 79, 236-244 (2015).

[10] V. Ducman, L. Korat, Materials characterization 113, 207-213 (2016).

[11] M.S. Cilla, P. Colombo, M.R. Morelli, Ceramics International 40, 5723-5730 (2014).

[12] D. Panias, I.P. Giannopoulou, T. Perraki, Colloids and Surfaces A. 301, 246-54 (2007).

[13] W.K.W. Lee, J.S.J. van Deventer, Colloids and Surfaces A. 211, 49-66 (2002).

[14] S. Kumar, R. Kumar, Ceramics International 37, 533-541 (2011).

[15] G. Mucsi, Á. Szenczi, Z. Molnár, J. Lakatos, Environmental Engineering and Landscape Management 24(1), 48-59 (2016). 